\title{
SUSTAINABILITY IN POLISH ROAD TRANSPORT SECTOR
}

\author{
Janusz, Grabara ${ }^{1}$ and Liviu, Mihaescu ${ }^{2}$ \\ Czestochowa University of Technology, Poland, janusz@grabara.eu \\ "Lucian Blaga” University of Sibiu, Romania, liviu.mihaescu@ulbsibiu.ro
}

\begin{abstract}
Today, road transport is the fastest-growing segment of the freight transport in Poland. Due to its dynamic development in the 90's and low barriers to entry of new transport companies the importance of this segment still growing. Low transport rates, the ability to reach every place, as well as high flexibility and reliability of supplies carried are the main advantages of this kind of transport. However, besides the advantages, road transport has disadvantages as well, and the biggest drawback of this type of transport is its negative impact on the environment through the emission of pollutants into the atmosphere. In addition, road transport is characterized by high land consumption and noise. This causes that the road transport sector is one of the sectors where actions from the field of sustainable development [1] are performed. This is due to the fact that currently the sustainability issues are very important and the present generation is aware that today's action will affect the quality of life for future generations. Therefore, road transport companies introduce measures to eliminate their negative impact on the environment or on social environment. This article describes the actions aimed at the practical implementation of the concept of sustainable development, conducted by the chosen transport companies.
\end{abstract}

KEY WORDS: transport, road, sustainable development, environment, social environment, economy

\section{INTRODUCTION}

Since the year 2004, when Poland joined the European Union, road transport continuously strengthening its position, particularly in the European rail freight market. And since 2009, has performed the biggest work of the shipping market, even selling off Germany. It is worth to underline that this result was achieved only thanks to the operators in this sector as in this activity there was no support from government or EU, in the form of subsidies or funding. It is only the result of market mechanisms, which always have an advantage over state intervention.

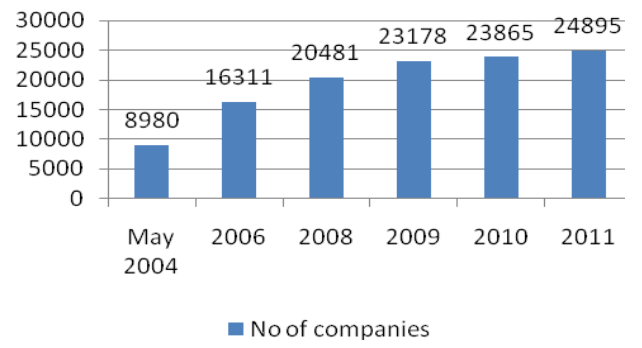

Figure 1. Number of companies operating in Road transport sector in Poland between May 2004 and 2011.

As presented in the above figure, the number of transport companies has tripled since Polish accession to the European Union. In addition, despite the financial and economic crisis still taking place in Poland, in transport sector, upward trend is still persisting.

Table 1. Changes in volume of traffic and transport work in road transport of goods in 2006-2010.

\begin{tabular}{|c|c|c|c|c|c|}
\hline Qty & 2006 & 2007 & 2008 & 2009 & 2010 \\
\hline $\begin{array}{c}\text { Th. } \\
\text { Tonnes }\end{array}$ & 1113880 & 1213246 & 1339473 & 1424883 & 1551841 \\
\hline Mln tkm & 136490 & 159527 & 174223 & 191484 & 223170 \\
\hline
\end{tabular}

The performance of the road transport companies is shown in the table 2, which shows the amount of revenue from the sale performed by this branch. The data illustrate the growing trend of revenues as well as the decelerating dynamics of this growth.

Table 2. Total revenues from road transport services in Poland in mln plz.

\begin{tabular}{|c|c|c|c|c|c|c|}
\hline 2000 & 2005 & 2006 & 2007 & 2008 & 2009 & 2010 \\
\hline 27 & 42 & 56 & 64 & 70 & 69 & 67 \\
021,9 & 185,4 & 757,4 & 043,2 & 036,3 & 731 & 733 \\
\hline
\end{tabular}

Changes in the exchange rate (EUR/PLZ) and changes in the price of fuel, especially diesel, are the factors that significantly affect the financial results.

As mentioned before, road transport in Poland is one of the fastest developing sectors of the Polish economy. A large number of companies providing transport services result in increased competition in the market, leading to lower transport rates or increase the level of reliability of realized supplies. On the other hand, road transport has a significant impact on the environment and the quality of life for the closest social environment, which presents a further part of this article.

\section{ROAD TRANSPORT AND ITS IMPACT ON ENVIRONMENT}

Transport provides a direct link between suppliers and customers, not only supporting economic development and social progress, but allowing people freedom to live and work. Given the high reliability of deliveries, road transport currently supports $80 \%$ of the land transport. Road transport is also a source of employment for more than 3 million people in Europe. Another 3 million people are employed in manufacturing, selling, servicing and repair of vehicles [2]. 
However, road transport is associated with many negative aspects of its business, such as:

- Land consumption caused by transport is manifested through the development of transport infrastructure on all of its branches. Road transport requires more and more dense road network and highways. These requirements cause that more forests and agricultural lands are divided into smaller parcels and their large part is designated for transport infrastructure development [3, 7]. According to the European Environment Agency, continuous development of roads and highways cause that continent will be divided into smaller lots, now, more than $30 \%$ of the entire territory of the continent is largely divided into smaller fragments [4].

- Contamination of the atmosphere by means of transport is one of the most dangerous effects on the environment and the social environment. Air pollution also causes that soil, plants and water are also intoxicated, causing ecological imbalance. The biggest impact on atmospheric pollution has road transport, because due to its size, it emits large amounts of gas into the atmosphere. In densely populated cities with high traffic intensity, the share of gas in air emissions can be up to $80 \%[5,8]$.

- $\quad$ Noise generated by road transport, has no negative impact on the environment, but it is very harmful for people. The most annoying noise is caused by the automotive industry, the intensity of which reaches up to $105 \mathrm{~dB}$, and the noise above $34 \mathrm{~dB}$ is already contributing to the loss of concentration.

- Changes in water system caused by road and highways constructions,

- Used oils and fluids, car wrecks are treated as a constant pollution,

- Accidents involving victims of fatal injuries, property damage, collision of trucks carrying dangerous substances,

However, on the other hand, road transport logs the biggest progress in the field of environmental protection. Over the past 20 years, funded investments in new technologies, by this branch, resulted in the introduction into service more and more modern vehicles that meet the highest standards of Euro norms (standard emission limits for vehicles) which are becoming more stringent. As a result of these actions, reduction of carbon monoxide emissions fell during this period by $88 \%$, hydro oxygen's by $95 \%$, nitrogen oxides by $97 \%$ and ashes by up to $98 \%$ [6].

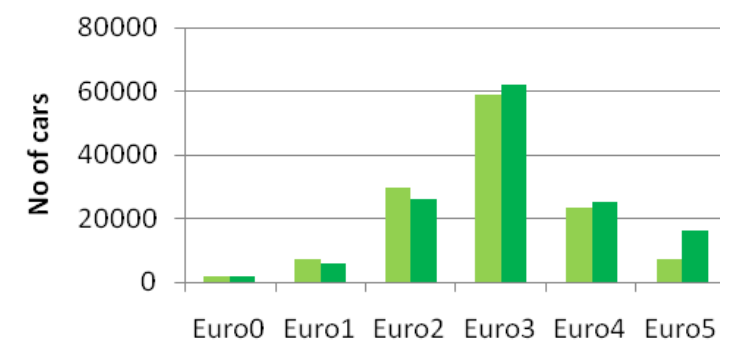

$2010 \square 2011$

Figure 2. Environmental performance of road transport fleet.

Slowly but steadily decreases the level of threat to life and health on the road. Since 2000, in Poland, the decline was $40 \%$, but the level of threat to life is still at a high level. However, it should be noted here, that the share of trucks, mainly used by road is much lower than passenger cars.

Since, in these days, being pro-ecological often brings tangible benefits, not only financial but also branding, transport companies try to implement solutions which have the effect of reducing the negative impact of transport on both the environment and society.

\section{ROAD TRANSPORT COMPANIES AND ACTIONS/SOLUTIONS TOWARDS SUSTAINABLE DEVELOPMENT CONCEPTION}

In this part of the article three companies will be presented, which are involved in the pursuit of supply both domestically and internationally. After their short presentation, the actions and tools, used by them to achieve sustainable development goals, are presented. As well as solutions from the sustainable management carried out by them.

\subsection{Company A}

Company $\mathrm{A}$ is one of the leaders in the market for courier services for institutional clients. Within a week, carrying four million parcels, documents and freight. Enterprises consists of more than 2,000 branches and points of handling and sorting centers, the company has a fleet of several thousand vehicles. The company employs more than 75 ths. employees and was the first company who gained the British emblem "Investor in people". The company offers a wide range of postal and courier services around the world. Further, in 2012, received the laurel "Logistics Operator of the Year", competed for the title of which more than 40 transport companies in Poland. It is worth to stress that the company was the only company, which three times was ranked on the first place in the ranking and never reached a lower place than the second. The size and the large operating area of the company that the company includes in its incorporate policy, the principles of sustainable development which in practice are implemented through the following activities:

- Establishment of an integrated management system consists of three subsystems: quality management, environmental and safety. In the first subsystem, the company has committed to providing excellent service in every area of the business. In the second subsystem, the company has committed to the use of best environmental practices such as by promoting a positive culture of the environment, which brings benefits for present and future generations. Taken actions covered the elements that have an impact on the environment:

- Office work - promoting solutions that lead to the creation of "green office",

- Activities performed in warehouses,

- Transport by office cars.

In the third subsystem, the company has committed to perform the best practice from the health and safety management, by promoting a culture of safety.

The company has been also active in the social field - since 2002, it is a partner UN World Food Programme Agency providing expertise in logistics, transport, food, fundraising, providing emergency aid and supporting the campaign feeding and education of poorest children in the schools. The company has also developed a corporate program "Planet Me" by placing the issue of environmental management in the midst of strategy and corporate culture. Additionally, the program relates to the 
personal involvement of employees in the aspects of environmental protection through the promotion of measures to reduce the negative impact on the environment. The company has a fully formulated policy of sustainable development in which the company's objectives and initiatives to the actual impact on all dimensions of sustainable development are formulated.

\subsection{Company B}

Company B has been operating on the market since 1970 and has a distribution system which will express that it is a leader in the fast and reliable delivery of a specified period, to more than 220 countries. It is now one of the largest transport companies, sending daily $3.6 \mathrm{mln}$ shipments. Company B was the first company introducing star-shaped structure models and tracking packages, allowing customers to receive information about the package at any time. In terms of sustainable development, the company has committed to provide global communication while minimizing its impact on the environment. By the conclusion of the responsible environmental practices into daily operations, the company is constantly working on reducing the amount of waste and air emissions. The company's goals include as follows:

- Reduction of aircraft by 20 percent by 2020 , based on the conversion issue in relation to the available tonnnes-miles,

- To increase vehicle efficiency by 20 percent by 2020 ,

- Developing own renewable energy system, and obtain sufficient credit for this purpose realization.

The company has made impressive progress in achieving the objectives of sustainable development: in 2011 the performance of the fleet has increased by 16.6 percent compared to the same period in 2005, 20 percent of the vehicles receiving and delivering the consignment has been converted to more efficient models. In addition to activities related to the transportation company, it has also introduced solutions to support sustainable development:

- In its hub, the company launched a solar power system that generates more than 800000 kilowatt-hours of electricity per year - the amount of energy meets the needs of 230 three-person households. This project represents the largest roof solar power installation in terms of area: covers an area of $16000 \mathrm{~m} 2$ roof.

- Another hub received ISO 14001 certification in 2011, making it joined the 50 facilities that have received the same certificate.

- Energy-efficient distribution center can reduce energy consumption by over $40 \%$ and reduce $\mathrm{CO} 2$ emissions by $60 \%$ per year.

- The distribution center has been equipped with solar panels that generate $144000 \mathrm{kWh}$, the amount of energy that could meet the needs of thirty households per year.

- The company's facility is equipped with a solar panel with an area of 16000 sq. $\mathrm{ft}$. which is able to produce 92000 kilowatt hours of electricity per year and the main conveyor belt with a low consumption of power, which consumes 16 times less energy than a standard carrierphase $380 \mathrm{~V}$, including the equipment can reduce emissions of 41.1 tons of $\mathrm{CO} 2$ per year

- The company's work has been recognized and highlighted by:

- Mention in the prestigious Maplecroft Climate Innovation Leaders' Index 2012,
- In February 2011, the company won the Dubai Award for Sustainable Transport (DAST) sponsored by the Roads and Transport Authority of Dubai (RTA) in the category of "Environmental Protection",

- Company has $122^{\text {nd }}$ place on the list of Top 500 Greenest Companies created by Newsweek magazine in 2011,

- For the fourth year in a row the company has received honorable mention in the ranking of Boston CollegeReputation Institute 2011 CSR Index.

Moreover, the company has committed to create the perfect job, thought the care of the environment and civic participation of local communities in which we live and work.

\subsection{Company $\mathrm{C}$}

Company $\mathrm{C}$ has been operating on the market for 15 years and now ranks among the largest and most dynamic courier for the Polish market. The company carefully analyzes the needs of the market and individual customers by offering solutions that are best suited to them. Its efforts focused mainly on improving the timeliness, speed, safety and reliability of supply. It has taken active measures to improve organizational effectiveness. The company has been actively involved in charity work and social and environmental programs. It supports various initiatives. In 2013, a project called Sevel-leaf Clover has been created, which focus on all company's activity across a wide range of CSR.

The best known of this type of activity is the annual bidding golden hearts in Finale of the Great Orchestra of Christmas Charity. Also, company supports the letter-writing marathon organized by Amnesty International. As part of corporate social responsibility strategy, the company is also actively involved in the ongoing support of smaller and less wellknown public benefit entities. These are:

- Lublin Hospice for Children. The Little Prince, which has been operating since 1997. It is only in South-Eastern home hospice for children. It was established to include home care of children and young people with cancer and other incurable and progressive disease.

- The Children's Home Janusz Korczak in Krasne has existed since 1948. Children's Home in Krasne serves as a socializing and intervention. In practice, this means that every child in need of support, may itself or with an adult to come to the orphanage and will receive appropriate assistance.

- Children's Fantasy Foundation is a non-profit organization that have the status of public benefit organization whose sole purpose is to bring a little joy into the lives terminally ill children. It does this by fulfilling their dreams came true.

Additionally, the company is working to increase the involvement of employees in the company's affairs as well as aspects of sustainable development.

\section{ACKNOWLEDGMENTS}

I would like to thank you all road transport companies for your time and given information about the sustainability and actions taken by them.

\section{CONCLUSIONS}

Currently, almost all the companies operating in the road transport sector, to a lesser or greater extent, fulfill assumptions of the concept of sustainable development. In the case of transport companies operating within international markets, 
these activities are undertaken on a large scale, they also cause their significant impact on the environment and the social environment. However, the fact that some transport companies operate only in domestic markets, does not that feel they are exempt from the obligation to take up and pursue activities consistent with the objectives of sustainable development. The effect of these measures is more local and social, concerns the immediate environment (eg, a particular city, municipality or county), but even such a small scale, actions taken by many companies, will have a significant impact on the environment, the level of life social environment while developing these businesses. However, there is the challenge for the state to provide an appropriate support programs and incentives to the smallest transport companies (employing up to 50 people), have begun to use measures and tools to support the implementation of sustainable development policies.

\section{REFERENCES}

1. "Sustainable development is a process of change in which the exploitation of resources, the direction of investments, the orientation of technological development; and institutional change are all in harmony and enhance both current and future potential to meet human needs and aspirations" from: Dumitrescu Luigi, Mihaescu Liviu, Mihaescu Diana, Managing Economic Solutions for a Global Sustainable Development, The 5th IASME / WSEAS International Conference on ENERGY \& ENVIRONMENT (EE,10), The Conference at University of Cambridge, Cambridge, UK, February 23-25, 2010,
ISBN978-960-474-159-5, ISSN1790-5095, pg151-155, index ISI,

2. "Logistyka w Polsce", Biblioteka Logistyka, ILIM, Poznań 2011,

3. Grabara J., Kot S., „Development of Polish Truck Transportation in Context of Polish Integration with European Union", W: Logistics Research Network 2001.Conference Proceedings. Edinburgh 2001,

4. European Environment Agency, „European transport sector mu be ambitious to meet targets", http://www.eea.europa.eu/pressroom/newsreleases/europe an-transport-sector-must-be, access on: 27.07.2013,

5. Bernhardt M., Michałowska J., Radzimirski S., „Motoryzacyjne skażenia powietrza”, WKit, Warsaw 2006,

6. Grabara J., „Urban Logistics in a Sustainable Development Concept on the Example of Transport System in Gdynia City", w: Valahian Journal of Economic Studies Vol.3 (17) Iss. $3 / 2012$

7. Kot S., Ślusarczyk B., "Sustainable Development Analysis in Transport Process." [in:] Szołtysek J. (ed.) Developing of Transportation Flows In 21st Century Supply Chains: Wyd. UE Katowice 2012

8. Ślusarczyk B., „Podstawy kosztów logistyki przedsiębiorstw". Wydawnictwo Wydziału Zarządzania Politechniki Częstochowskiej, Częstochowa 2011 